\title{
TERITORIALNO OBLIKOVANJE REPUBLIKE SLOVENIJE V 20. STOLETJU IN UČINKI NA NJENO VARNOST
}

\author{
Marjan Grabnar*
}

Izvleček:

UDK: 911.3:355(497.4)

S Slovenci poseljen prostor se je od $75.000 \mathrm{~km}^{2} v 18$. stoletju skrčil na $20.256 \mathrm{~km}^{2}$. Geopolitični pomen tega prostora je bil, je in bo ostal izjemno pomemben. Republika Slovenija je $v$ obdobju osamosvajanja namenila izredno pozornost svojim mejam in $z$ vojaškega vidika izdelala in izvedla pomembne načrte o varovanju meje.

Ob spremenjenih geopolitičnih razmerah meje in "sporna « obmejna območja lahko postanejo predmet sporov in zaostrovanj.

$Z$ demokratičnim razvojem z ekonomsko blaginjo in prizadevanjem za članstvo v Evropski skupnosti in Natu je Sloveniji dolgoročno zagotovljen stabilen geopolitični položaj.

Ključne besede: geostrateški, geopolitični položaj, teritorij, meje, obmejno območje, samostojnost.

\section{TERRITORIAL FORMING OF THE REPUBLIC OF SLOVENIA IN $20^{\text {TH }}$ CENTURY AND EFFECTS ON ITS SECURITY}

\begin{abstract}
:
The area, whose population are Slovenians was reduced through centuries from 75.000 $\mathrm{km}^{2}$ in the $18^{\text {th }}$ century to $20.256 \mathrm{~km}^{2}$. The geopolitical meaning of this area was, is and will forever be extremely important. During the independence period Slovenia has shown great attention towards the borders. Slovenia also made and carried out very important plans from military point of view how to secure the borders.

Borders and the "controversy frontier areas could become a part of conflicts and could become tense in this part of Europe.

With the democratically development, economical prosperity in the future and with an active effort of Slovenia to become a member of UE and NATO, Slovenia will have on a long term, stabile geopolitical position.
\end{abstract}

Key words: geostratigical, geopolitical position, territory; borders, frontiers, independence.

* General podpolkownik in univerzitemi diplomiran organizator dela. Nařelnik Verifikacijskega centra Slovenske vojske. 


\section{UVOD}

Referat prikazuje teritorialno oblikovanje Republike Slovenije (RS) v 20. stoletju in možne vplive in učinke na njeno varnost $\mathrm{v}$ prihodnje. Tematika je povezana $\mathrm{z}$ mojim delom $\mathrm{v}$ Slovenski vojski (SV) v preteklem obdobju, ko sem bil načelnik operativnega oddelka Republiškega štaba teritorialne obrambe (RŠTO) oziroma General štaba Slovenske vojske (GŠSV). Ugotovitve tega referata so lahko tudi delovna podlaga in pripomoček pri nadaljnjem načrtovanju razvoja in uporabe SV. Pri izdelavi referata je bila uporabljena številna strokovna literatura, nekatere knjige, zakonski in podzakonski predpisi (RS), mednarodne pogodbe in sporazumi s tega področja, gradivo državnih in drugih organov ter nekateri osebni viri avtorja, zlasti zabeležke iz priprav na vojno za Slovenijo 1991, v času te vojne in neposrednem povojnem obdobju, v katerem je sodeloval.

V celotni zgodovini Slovencev je bilo slovensko nacionalno ozemlje vedno predmet osvajanj-prisvajanj, zlasti s severa in zahoda, tudi v 20. stoletju. Zato lahko to zadnje obdobje v 20. stoletju na kratko poimenujemo za tri boje za meje Slovenije:

- obdobje 1919 - 1920

- obdobje 1945 - 1975

- obdobje 1990 - 1991

\subsection{Nekatere geografske poteze Slovenije}

Prostor današnje Republike Slovenije in s Slovenci poseljen prostor v Italiji, Avstriji in Madžarski je bil v celotni zgodovini, celoten čas, kulturno, prometno, gospodarsko in politično geografsko pomembno prehodno območje v tem delu Evrope ${ }^{1}$.

Zaradi takšnega položaja, križiščnih in prehodni, se je slovenski narod že od sedmega stoletja dalje boril za svoj poselitveni prostor, za svojo kulturo, za svoje preživetje.

Zgodovinsko gledano smo bili večno na »prepihu«, po eni strani smo imeli določeno prednost, po drugi pa zlasti močne »težnje« po našem ozemlju, kar nam je prineslo številne delitve v posamezne tuje države, boleče zmanjševanje etičnega ozemlja ter potujčevanje Slovencev.

\subsection{Prometna, politično geografska, kulturna in gospodarska pomembnost tega prostora}

Ozemlje RS se nahaja na pomembnem stičišču strateških poti vojska v sodobni zgodovini, na križišču prometnih povezav Srednje Evrope s Sredozemljem, Zahodne Evrope z Bližnjim vzhodom, pomembne povezave jugozahodne Evrope s severovzhodno Evropo, na stičišču velikih etičnih grupacij kot so Romani, Germani, Ugrofinci in Slovani, ki so oblikovale sodobno zgodovino na stičišču zahodne in orientalske civilizacije ter na stičišču političnih interesov med tradicionalnima političnima in gospodarskima antipodoma zahodno Evropo in Rusijo.

Posebnost politično in mednarodno pomembne prometno-tranzitne lege sta Sloveniji narekovali v njenem družbeno-gospodarskem razvoju večjo prožnost, policentrični družbeni in regionalno-prostorski razvoj.

Intenzivno prek mejno povezovanje Slovenije je vplivalo tudi na drugačne predstave in oblikovanje človekovih pravic in sicer zlasti v okviru manjšinske zaščitne zakonodaje za

I - na severu »alpsko območje«,

- na vzhodu in severovzhodu »subpanonsko in panonsko območje».

- na jugozahodu »submediteransko območje«.

- na jugovzhodu "dinarsko kraško območje». 
madžarsko in italijansko manjšino na eni strani ter na civiliziran način vztrajnega postavljanja zahtev Slovencev kot matičnega naroda za zaščito slovenske manjšine v Italiji, Avstriji in na Madžarskem na drugi strani.

\section{TERITORIALNO OBLIKOVANJE SLOVENIJE V 20. STOLETJU}

\subsection{Teritorialno oblikovanje Slovenije do suverene države}

Teritorialno oblikovanje ozemlja Republike Slovenije (RS) je potekalo od druge polovice 19. stoletja, od tako imenovane »pomladi narodov« leta 1848 ter celotno 20. stoletje. S politično vztrajnostjo je slovenskemu narodu uspelo $\mathrm{v}$ evropsko pomembnem geopolitičnem prostoru postopoma izoblikovati upravno-politično teritorialno enoto, ki od 2. svetovne vojne dalje vključuje večji del s Slovenci poseljenega prostora.

Avstroogrska monarhija je bila do I. svetovne vojne praktično »lastnica« velike večine celotnega današnjega državnega ozemlja.

Zgodovinske težnje Slovencev po svoji državi so se uresničile po prvi svetovni vojni, ko so se posamezne dežele združevale $\mathrm{v}$ upravno politično enoto $\mathrm{z}$ nazivom Slovenija in sicer:

- iz avstrijskega dela monarhije: Kranjska, Štajerska in del Koroške,

- iz ogrskega dela: Prekmurje.

Tako se je takratna Slovenija združila v Državo Slovencev, Hrvatov in Srbov (SHS). Ta tvorba se je 1. decembra 1918 združila s Kraljevino Srbijo in Kraljevino Črno goro v Kraljevino Slovencev, Hrvatov in Srbov. Žal je velik del zahodne Slovenije ostal izven nove državne tvorbe in pripadal po »Rapalski pogodbi « Italiji.

Po drugi svetovni vojni, dokončno pa z Osimskimi sporazumi leta 1975, je velik del slovenskega etičnega ozemlja ponovno pripadel Slovencem.

V vojni za Slovenijo v obdobju 1990 - 1991 je bilo dokončno oblikovano državno ozemlje Republike Slovenije, saj so meje z Republiko Italijo, Avstrijo in Madžarsko dokončno urejene, z Republiko Hrvaško pa praktično več kot $98 \%$.

Zato lahko teritorialno oblikovanje Republike Slovenije strnemo v tri boje za meje Slovenije:

\section{* prvi boj za meje Slovenije}

Ko si je Slovenija ob razpadu Avstro-Ogrske pridobila delno suverenost, ne sicer kot samostojna država, temveč kot federalna enota v okviru Države SHS, je bila njena prva naloga, da to suverenost uveljavi na narodnostnem ozemlju, ki pa ni bilo v nobenem pravnem aktu nedvoumno določeno. Ozemeljske zahteve je morala Slovenija uveljavljati proti Italiji, Avstriji in Madžarski. Pogajalsko izhodišče ni bilo dobro, zlasti pri pogajanjih za mejo z Italijo so bili slovenski politiki v težavnem položaju. Težavna pogajanja z Italijo so se končala z Rapalsko pogodbo. Pogajanja z Avstrijo so bila v znamenju plebiscita na Koroškem v letu 1920. Podlaga za določitev meje z Madžarsko je bil Trianonski sporazum, podpisan 04. 06.1920

\section{* drugi boj za meje Slovenije}

Ker je bila Jugoslavija po končani drugi svetovni vojni na strani zmagovalcev. ne glede na to, da je med vojno izvedla revolucijo in vzpostavila totalitarni družbeni sistem, je upravičeno terjala pravico, da sodeluje pri povojnem urejanju meja, zlasti tistih, ki so ostale sporne od njihovega nastanka po prvi svetovni vojni. Ugodno rešitev je lahko pričakovala, ker so bile države z narodnostno spornimi mejami na strani premaganih in še posebej, ker 
so enote jugoslovanske vojske (slovenska je bila ob koncu vojne ukinjena) zasedle ozemlja, ki naj bi pripadla Jugoslaviji. Avstrijsko-jugoslovanska meja in madžarsko-jugoslovanska meja sta ostali nespremenjeni. Italijansko-jugoslovanska je bila dokončno določena z Osimskimi sporazumi. Meja z Hrvaško pa je postala republiška.

\section{* tretji boj za meje Slovenije}

O boju za meje leta 1991 govorimo pogojno. Današnje slovensko državno ozemlje je praktično identično tistemu, ki ga je imela Republika Slovenija v okviru SFRJ. Čeprav je bil neposredni cilj jugoslovanske vojske zasedba meja, ki ločujejo Slovenijo od Italije, Avstrije in Madžarske, je bil to le način, s katerim so jugoslovanske oblasti skušale preprečiti dejanski prevzem oblasti demokratično izvoljenim organom v Sloveniji, ko je ta proglasila svojo samostojnost in neodvisnost.

\subsection{Geostrateški in geopolitični položaj Slovenije}

\subsubsection{Geostrateški položaj Slovenije}

Geografski položaj ozemlja RS je izjemno pomemben saj prek nje potekata dve geostrateški smeri:

* severozahod-jugovzhod v slovenski zgodovini, znan po pohodih Nemcev na »topla morja« kot so pristanišča Trst, Koper, Reka in »Drank nach Osten«, kot zgodovinska zveza Berlin-Bagdad oz. prometni izhod v Perzijski zaliv in neposreden trgovinski pristop na bližnjeazijsko tržišče;

* jugozahod-severovzhod, v vojaškem smislu prehod iz Padske v Panonsko nižino, v smislu prometnih povezav pa Barcelona-Kijev.

Prek tega prostora vodijo najkrajše kopenske komunikacije iz zahodne oziroma srednje Evrope, v Podonavje, na Balkan ter naprej v Azijo, prav tako pa iz srednjeevropskega prostora vodijo najugodnejše smeri do jadranske obale in Apeninskega polotoka.

V vojaškem smislu Slovenija leži na severnem delu južnoevropskega bojevališča, saj prek nje poteka glavna strateška smer tega bojevališča - iz Panonske v Padsko nižino in obratno.

\subsubsection{Geopolitični položaj Slovenije}

V zadnjem desetletju smo preživeli dramatične spremembe in preureditev razmerij v svetovni skupnosti. Primerljiva je s tisto v letih 1945-1950. Odpravljene so bistvene posledice druge svetovne vojne in delitve sveta vzdolž ideoloških meja med kapitalizmom in socializmom, »Hladne vojne « ni več. Razpad bivše Sovjetske zveze, s tem nastanek številnih novih držav na ozemlju bivše SZ je zelo zaznamovalo zadnje desetletje. Rusije ne štejemo več kot velesilo, ohranila je le nekatere njene vojaške lastnosti, predvsem v obliki strateške jedrske oborožitve.

Močno se je dvignil pomen Zahodne Evrope in Japonske. V tretjem svetu so se okrepile regionalne sile - hegemoni kot so Kitajska, Indija, Brazilija, Nigerija in druge. Za Evropo je značilno združitev Nemčije, ki je tako postala prva evropska gospodạrska sila, ki se tudi vojaško vse bolj uveljavlja, zlasti v zadnjem obdobju na Balkanu.

Edino prava sodobna, politična, gospodarska, gospodarsko tehnološka in vojaška supersila so ostale Združene države Amerike (ZDA). ZDA bodo še naprej prisotne v Evropi, vendar bodo prenašale večji del svojih zadolžitev na združeno Nemčijo in Italijo.

Nekateri avtorji v zadnjem obdobju, zlasti po letu 1990, govorijo o »doktrini« geopolitičnega položaja Slovenije. Ta »doktrina« predvideva: 
1. Slovenija je prometno prehodno ozemlje, še zlasti $v »$ Ljubljanskih vratih «

2. Slovenija in s Slovenci poseljeno ozemlje preprečuje in zapira Nemcem dostop do Jadrana oziroma ovira njihove stoletne interese in težnje po nadzoru prostora od Baltika do Jadrana.

3. Novo nastajajoči Podonavski trikotnik Praga-Budimpešta-Dunaj potrebuje najbližje pomorske izhode k severno-jadranskim pristaniščem (Trst, Koper, Reka). S tem Slovenija pridobiva na pomenu

4. Smer severozahod-jugovzhod (Jesenice-Zagreb-Beograd-Atene-Mala Azija) je za Zahod izjemnega pomena, ker je po tej smeri povezan z Balkanom in Bližnjim vzhodom

5. Smer jugozahod-severovzhod (Gorica/Koper-Maribor-Lendava) povezuje najbolj oddaljene predele Slovenije in odpira pota na vzhodnoevropska tržišča, v evropskem smislu pa je to del smeri Barcelona-Kijev.

6. Za Slovenijo sta glavna geopolitična cilja: Evropska skupnost (ES) in Nato.Temu cilju se bolj ali manj uspešno približujemo, saj smo pridruženi člani ES in člani partnerstva za mir od marca 1994.

\subsection{Pravni vidiki meje}

\subsubsection{Opredelitev pojma}

Zakon o nadzoru državne meje je sprejela samostojna in neodvisna država Slovenija in je bil objavljen v prvi številki Uradnega lista Republike Slovenije, dne 25.6.1991, hkrati z objavo Temeljne ustavne listine o samostojnosti in neodvisnosti Republike Slovenije. Peti člen omenjenega zakona določa državno ${ }^{2}$ mejo kot: ... prostor treh dimenzij, ki se razprostira nad zemeljsko površino $v$ višino, na površini tal in $v$ zemeljsko globino. $V$ istem členu je pojasnjen tudi pomen izraza mejna črta, ki je namišljena ali označena črta, ki po kopnem, morju, rekah in jezerih deli območje Republike Slovenije od območja sosednje države.

Probleme povezane $z$ državno mejo obravnava mednarodno pravo. Rešitve za posamezne probleme pa povzema iz mednarodnih sporazumov, ki so bili doseženi ob reševanju konkretnih primerov. Pravila, ki jih morajo glede državnih meja spoštovati posamezne države in so zajeta v mednarodnih sporazumih, so nastajala vzporedno z razvojem družbe in njenimi tehnološkimi dosežki. Tudi razumevanje pojma državna meja se je s časoma spreminjalo ${ }^{3}$.

Državna meja določa območje države oziroma teritorij države. Državno območje v običajnem pomenu je prostor znotraj meja na kopnem, skupaj z obalnim morjem in zračnim prostorom 4 .

2 Pri tem pa Gojmir Mlakar v knjigi "Meje posestne in državne - EPSI d.o.o. Nazarje. 1990 na strani 39 nasprotuje tej definiciji, saj pravi: Definicija ni dobra, saj državna meja ni prostor; ki ima tri dimenzije, tem-

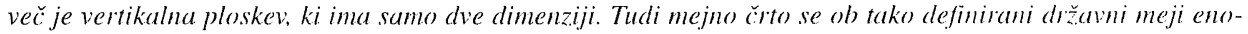
stavneje definira. Lahko bi rekli: mejna črta je presek državne meje z. zemeljsko površino.

$3 \breve{C}$ je potreba po definiranju državnega teritorija iz površja v globino nastala takoj ob nastanku državnih skupnosti, je potreba po opredelitvi zračnega prostora posamezne države nastala kasneje. in kot bomo videli v nadaljevanju, še danes ni povsem rešena. Tudi pravice na morju, ki obdaja posamezno državo. je bilo treba zaradi ribolova kmalu po nastanku državnih skupnosti opredeliti. Z možnoștjo izkorišr̆anja rudnega bogastva pod morskim dnom pa je bilo treba opredeliti tudi pravice na tem delu semeljskega poiršja.

4 Državno območje je prostor izključujoče državne pristojnosti. ta pa se v širšem pomenu nanaša tudi na ladje $v$ mednarodnih vodah, letala v začnem prostoru ter stavbe s funkcunalnimi zemljišri, ki pripadajo diplomatskim predstavništvom. Dižavno območje je običajno strnjeno. so pa tudi dragačrni primerr, najbolj poznan primer drăave v dieh delih je bil Pakistan v letih od 1947 do 1972 
Prilogo $\mathrm{k}$ tem zakonskim in podzakonskim aktom ter določilom mednarodnega prava kot dejansko pravno tehnično gradivo o meji prištevamo:
a) opis meje;
b) seznam koordinat in
c) mejni načrt.

\subsection{Pomembnost meje $v$ procesu osamosvajanja Slovenije v obdobju1990/1991}

\subsubsection{Nekateri pomembni politični dogodki v Sloveniji po Titovi smrti in $»$ procesu proti četverici«}

Po Titovi smrti je bilo v bivši Jugoslaviji zaznati težnje centralizacije in nevarnost izgube že tako omejene suverenosti. To nevarnost so zaznali zlasti: humanistična inteligenca, predvsem pa književniki zlasti leta 1983 ob poskusu uvedbe »skupnih jeder« v šolske učne programe.

Leta 1987 izide 57. številka Nove revije (februar 1987) v celoti posvečena slovenskemu narodnemu programu.

Leta 1988 aretirajo Janeza Janšo in organizirajo proces proti četverici. Formira se Bavčarjev odbor po aretaciji Janše, Borštnerja, Tasiča in Zavrla

Leta 1988 nastaneta Kmečka zveza in Slovenska demokratična zveza kot znanilki prihajajočega večstrankarskega sistema.

8.5.1989 se v Majniški deklaraciji pojavi zahteva po popolni suverenosti.

22.6.1989 Zveza komunistov Slovenije (ZKS) objavi Temeljno listino, s katero sicer terja suverenost, vendar znotraj Jugoslavije.

27.9.1989 so bili sprejeti amandmaji k ustavi RS, s katerimi je bila črtana vodilna vloga ZKS.

7.3.1990 je bila $\mathrm{z}$ amandmajem črtana beseda »Socialistična«iz uradnega naziva RS.

8.1 .1990 - razpis volitev.

8.4.1990 Izvedba volitev in zmaga DEMOSA, ki so ga sestavljali: SDS - slovenska demokratska zveza; SKZ - slovenska kmečka zveza; SKD - slovenski krščanski demokrati; SDSS socialdemokratska stranka Slovenije; LS - liberalna stranka in ZS - zeleni Slovenije.

Junija 1990 parlament sprejme deklaracijo o suverenosti RS s katero so potrjena načela »majniške deklaracije«.

23.12.1990 na Plebiscitu za samostojno Slovenijo (udeležba 93,2\%, je »ZA« glasovalo $82 \%$ volilnih upravičencev

Marec 1991 - »deklaracija za mir«, ki jo podpiše tudi predsednik Milan Kučan.

Marec 1991 - skupščina RS sprejme ustavni amandma oz. Zakon za izvedbo 96. in 97. člena ustavnega amandmaja k slovenski ustavi, po katerem je bil uveden moratorij za opravljanje vojaške obveznosti v Jugoslovanski ljudski armadi (JLA).

15.5.1991 sta bila formirana učna centra Pekre in Ig in začeto z usposabljanjem nabornikov v Teritorialni obrambi (TO) Slovenije.

24. junij 1991 - stoti amandma k ustavi RS s katero so določili novo zastavo in grb Slovenije

25. junij 1991 - sprejeti:

1) Temeljna ustavna listina o samostojnosti in neodvisnosti Republike Slovenije;

2) ustavni Zakon za izvedbo Temeljne ustavne listine in

3) Deklaracija o neodvisnosti. 


\subsubsection{Načrt »Kamen«}

Obrambni minister Janez Janša je večkrat opozarjal, da je potrebno proces osamosvajanja vojaško zavarovati.

Tako je že v začetku leta 1991 (14.02.1991) izvedena štabna vojna vaja (ŠVV) »Kobra 91 « po katerem so takratni 2., 8. in 7. Pokrajinski štabi TO (PŠTO) zavarovali »južne meje«. Del sil je bil premeščen iz zahodnega dela na jugovzhodni del meje.

Od 20. do 22. 03. 1991 je TO Slovenije izvedla vajo »Premik 91 « na Primorskem in Dolenjskem Sodelovali so Republiški štab TO (RŠTO), 6. PŠTO in 2. PŠTO ter 1. specialna brigada (spbr). 29.03.1991 je potekal posvet operativnih organov TO Slovenije v Kostanjevici na Krasu. Posvet vodil podpolkovnik Danijel Kuzma, ki je bil načelnik operativnega oddelka RŠTO. Takratna ocena načelnika operativnega oddelka RŠTO in dogajanj v zvezi z mejo je obsegala štiri faze in določitev ukrepov TO:

I. faza: - zaostritev z JLA

Ukrepi:

- povečati obveščevalne aktivnosti na nivoju RS;

- milica okrepi prisotnost na meji, opremljena z zaščitno opremo in avtomati;

- povečati število miličnikov na meji - nekatere mejne prehode posebej okrepiti - primer Ljubelj;

- TO - oblikovati dežurne enote na mejah;

II. faza: - JLA zasede mejne prehode, da bi izrinila milico z meje.

Ukrepi:

- Pokrajinam določiti rezervne mejne prehode.

III. faza: JA s silo zavzame mejne prehode.

Ukrepi:

- Razglašene so izredne razmere. TO s silo prevzame nadzor nad mejo.

IV. faza: Pokrajine na meji s Hrvaško zasedejo in varujejo mejo.

Načrt Kamen ${ }^{5}$ je vseboval:

a) obrambno oceno meje ${ }^{6} \mathrm{z}$ Italijo, Avstrijo in Madžarsko ter z republiko Hrvaško

b) Kamen - 1 se ujema s predhodnim pojasnilom o I. Fazi;

c) Kamen - 2 se ujema s predhodnim pojasnilom o II. Fazi.

$\mathrm{V}$ načrtu Kamen so bile opredeljene naloge in povelje štabom in enotam:

»V primeru da JLA okrepi sile na mejah ter razglasitve izrednih razmer izvršiti kontrolo in blokado na pomembnih komunikacijah in zagotoviti vsaj en prehod prek državne meje:

4. PŠTO: Škofije, Repentabor

6. PŠTO: Rožna dolina - alternativa Erjavčeva cesta

3. PŠTO: Jesenice, Jezersko

5 Dejansko je bil ukaz za načrt KAMEN kot POVELJE POVELJNIKA TO RS ZA BOJNO DEJSTVOVANJE PO NAC RTU „KAMEN« izdelan nekoliko pozneje in sicer s podpisom generala Janeza Slaparja z dne 19. (1) 1991 št. SZ 804-03/112. V povelju je bil načrt »Kamen《 izdelan v štirih variantah, ki se dejansko ujemajo s tistim kar je polkovnik Danijel Kuzma predstavil na posvetu operativcev in načelnikon štabov PŠTO in 30. I. spbr:

6 Po takratni oceni je JLA imela na razpolago za zavarovanje meje naslednje sile: - meja z. Italijo, ki so jo nadzirali 61., 62.. 63. in 64. obmejni odsek zokoli 1300 vojaki v 20) stražannicah. - meja z. Avstrijo, ki so jo nadzirali 61., 65 in 67. in 66. obmejni odsek zokoli 1900 vojaki r +4 stră̌armicah. - meja z. Madžarsko, ki jo je nadziral 65 . obmejni odsek z. okoli 750 iojaki v 12 stražarnicah. - meja s Hrvaško. Na njej ni bilo enot JLA, ker je bila to takrat republiška meja. Po oceni RŠTO naj bi za mejo s Hrvaško 2., 4., 7. in 8. PŠTO angažiralo okoli 1350 vojaških obveznikov (vo) s 45 stražarnicami. 
8. PŠTO: Libeliče

7. PŠTO: Jurij ali Plač, Gornja Radgona oz. Cankova, Dolga vas.

č) Kamen - 3 je predvideval nasilno odpiranje mejnih prehodov s strani TO, v kolikor bi JLA uspela zavzeti vse mejne prehode in sicer:

4. PŚTO: Voglje ali Gropado

6. PŠTO: Opatje Selo ali Valerišče

3. PŠTO: Karavanke (v gradnji) in Ljubelj

8. PŠTO: Mežica (Reht)

7. PŠTO: Gradišče, Sotina in Martinje«

d) Kamen - 4 je predvideval umik enot JLA meje z Italijo, Avstrijo in Madžarsko ter zavzetje objektov na meji s TO, mejne prehode pa bi prevzele enote milice.

$\mathrm{Na}$ meji s Hrvaško je bilo predvidena vzpostavitev določenega števila stražarnic z nalogo zavarovanja in kontrolo le-te po principu en območni štab - en obmejni odsek. V vsako stražarnico oz. na vsaki lokaciji zagotoviti enote TO moči enega strelskega voda okoli 25 - 30 v/o. Predvidevali so tudi oblikovanje begunskih centrov in v sodelovanju z upravami za notranje zadeve (UNZ) omogočiti vzpostavitev mejnih prehodov. Tako je bilo po načrtu Kamen - 4 za zavarovanje celotne meje vzpostavljeno 199 stražnic.

17.09.1991 je RŠTO posredoval »Dopolnitev načrta »KAMEN« št. SZ 804-03/619« kot popolno kontrolo meje s posebnim poudarkom na meji s Hrvaško. Izdelan je bil v:

varianti I. - popolna kontrola meje in varianti II. - popolna zapora meje.

Iz načrta »KAMEN« ni možno ugotoviti števila vojaških obveznikov TO, ker so v nekaterih načrtih navedene samo enote, v nekaterih pa tudi številčni pregledi. Na karti RŠTO iz 1. 1991 pa tudi ni zbirnika?

Iz vsega navedenega sledi, da se je takratno politično in vojaško vodstvo jasno zavedalo pomena meja in njenega nadzora, zato je bil načrt »KAMEN« eden najpomembnejših v času osamosvajanja Slovenije in ga bo v naslednjih obdobjih potrebno poglobljeno proučevati.

\subsection{Meja v samostojni Republiki Sloveniji}

\subsubsection{Zgodovinski razvoj}

Sedanja slovenska državna meja je z majhnimi izjemami tudi etnična meja slovenskega naroda. Toda v prejšnjih letih in stoletjih ni bilo tako. Še v začetku 20. stoletja je v slovensko etnično ozemlje spadala skoraj vsa Koroška, del današnje avstrijske Štajerske ter deli Furlanije Julijske krajine v Italiji. Če pogledamo še dlje v preteklost, ugotovimo, da so Slovenci izgubljali nacionalno ozemlje predvsem na severu, kjer so se umikali Nemcem, nekoliko manj na zahodu, kjer ni prišlo do bistvenih sprememb, medtem ko se južna in vzhodna meja s Hrvati skoraj ni spreminjala.

\subsubsection{Meja Republike Slovenije}

Slovenija je, kot samostojna in suverena država, dobila svoje meje z razglasitvijo samostojnosti. Slovenska skupščina je 25. junija 1991 sprejela osamosvojitvene akte, s katerimi je Slove-

7 Tako lahko le okvirno ocenimo številčno angažiranje za ta načrt. Po podatkih za 8. PŠTO je bilo predvideno za načrt Kamen 1834 vojaških obveznikov in za 2. PŠTO 303 vojaških obveznikov. Ocenjujem, da je bilo za zavarovanje meje angažirano med 700 in 1000 vojaških obveznikov, vendar to ni zanesljiv podatek. 
nija postala samostojna in neodvisna država. Najpomembnejši osamosvojitveni dokument, ki je bil takrat sprejet, je Temeljna ustavna listina o samostojnosti in neodvisnosti Republike Slovenije. Ta določa, da je Republika Slovenija samostojna in neodvisna država in kot taki tudi opredeljuje njene meje, ko v drugem poglavju pravi: »Državne meje Republike Slovenije so mednarodno priznane državne meje dosedanje SFRJ z. Republiko Avstrijo, z Republiko Italijo in Republiko Madžarsko v delu, v katerem te države mejijo na Republiko Slovenijo, ter meja med Republiko Slovenijo in Republiko Hrvatsko v okviru dosedanje SFRJ." 8

\subsubsection{Meja z Avstrijo}

\section{- Pravno zgodovinski vidik}

Meja med Republiko Slovenijo in Republiko Avstrijo je povzeta kot državna meja med Kraljevino SHS (kasneje SFRJ) in Avstrijo, ki je bila določena s Saint-germainskim mirom po prvi svetovni vojni. Ta določila so bila vnešena tudi v Državno pogodbo o vzpostavitvi neodvisne in demokratične Avstrije, podpisane 15.05.1955 (poleg velikih sil in Avstrije je bila podpisnica tudi takratna FLRJ).

Po prvi svetovni vojni je bil na Koroškem izveden plebiscit ${ }^{9}$. Na njem so se morali prebivalci odločiti o tem, ali želijo priključitev h Kraljevini SHS ali Avstriji.

Največ zaslug potek meja med Avstrijo in Slovenijo na Štajerskem po etični črti ima poleg A. M. Slomška slovenski general in pesnik Rudolf Maister.

\section{- Odprta mejna vprašanja in možni učinki na varnost}

Avstrija je ena izmed nevtralnih držav Evrope. Tudi z Avstrijo so meje pravno urejene. Omenili smo edinstveni primer $»$ Libelič ${ }^{10}$, je pa izguba nesporno slovenskega dela Koroške pod reko Dravo za naš narod izredno boleča. Zato lahko za severno mejo rečemo, da s strani Avstrije ni pričakovati kakršnihkoli zahtev, kljub temu, da se tudi na avstrijskem Koroškem občasno s strani desničarjev (Heimatdienst) pa tudi uradne koroške politike, kot

8 Republika Slovenija meji na štiri države: Italijo, Avstrijo, Madžarsko in Hrvaško. Približna skupha dolžına kopne meje države Slovenije znaša 1.334 kilometrov, približna dolžina morske meje pa 30 kilometrov (46 km - zelo različni podatki). O približni dolžini meje Republike Slovenije bomo govorili do takrat, ko bo dokonĭno določena in geodetsko izmerjena meja z. Republiko Hrvaško, in to njen kopni in morski del.

Dolžine in vrste meja, ki pripadajo posameznim mejnim državam. so:

Italija: $232 \mathrm{~km}$, od tega $201 \mathrm{~km}$ kopenske, $31 \mathrm{~km}$ rečne, za morsko ni podatka.

Avstrija: $330 \mathrm{~km}$, od tega $251 \mathrm{~km}$ kopenske, $79 \mathrm{~km}$ rečne,

Madžarska: $102 \mathrm{~km}$, od tega $89 \mathrm{~km}$ kopenske. $13 \mathrm{~km}$ rečne.

Hrvaška: $670 \mathrm{~km}$, od tega $380 \mathrm{~km}$ kopenske, $290 \mathrm{~km}$ recne, za dolžino morske meje ni podatka.

Vir: Mlakar; G., 1996: Meje, posestne in državne. EPSI, d.o.o., Nazarje

9 Dne 16. julija 1920 je bilo odločeno, da se bo plebiscit izvedel v nedeljo 10. oktobra I920. V glasoralmi coni A je v

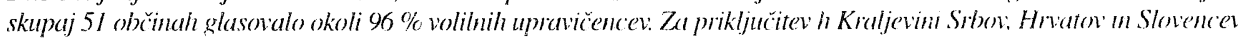
se je izreklo 15.279 glasovalcev ali $40.96 \%$, za priključitev k Republiki Awstriji pa 22.025 glasoralcev ali $59.04 \%$. Glede na to, da je cona A pripadla Avstriji se, v coni B vakladu s. 50. clenom mironne pogodise plehscit sploh mi izvajal, ampak je antomatsko pripadel Avstriji. Tako je na avstrijskem Koroškem ostala številna slonenska mamjšina. ki pa se zaradi raznarodovanja še vedno zmanjšsuje. Tudi po II. svetonni vojni je takratha Jugoskanija pomonno sprožila koroško vprašanje. pa je bila na konferenci štinih velesil in Avstrije mạja in junija 1949) njena zahteva zanrnjena.

10 Ena od svetlih točk y zgodovini slovenskega naroda so Libeličani. Na plebiscitu 10.10.1920) se je od 70)4 glasonalnih upravičencev plebiscita udelě̌ilo 677 upravičencev: $57,16 \%$ oz. 387 glasov je bilo za priključitev h Kraljevini SHS in za Avstrijo je bilo $42,84 \%$ oz. 290 glasov. Ne glede na ta izid so po miromi pogodbi Libelice pripadle Avstriji. Libelicani so takoj po tem izidu - pripadnost Avstriji dojeli da kot Slovenci v Avstriji nimajo prihodnosti. Zato so tako prebivalci, kot župnik Anton Vogrinec, upravitelj Janko Gačnik in šolski nadzonnik Rudolf Mencin vatrajali, da se njihos: kraj priključi h Kraljevini SHS. kar so dosegli na razmejitieni konferenci 1922 v Mariboru. 
so s strani deželnega glavarja Jörga Haiderja »čudne zahteve« v zvezi s priznavanjem nemške manjšine v Sloveniji, sprememba ustave in premoženjsko pravne zahteve.

Po drugi strani pa si Avstrijci vztrajno prizadevajo za zaprtje JE Krško, kot nevarnost za Avstrijo oz. Srednjeevropski prostor. Pri tem zlasti koroški desničarski politiki rešitev - oz. zaprtje JE Krško pogojujejo s soglasjem Avstrije za vstop Slovenije v polnopravno članstvo EU.

Varnost Slovenije je lahko ogrožena tudi v primeru porušitve jezu na He Golica v Lavamündu. Ta leži na avstrijski strani Bistrice okoli $8 \mathrm{~km}$ od meje v povodju Krumbach. Tako je dolina Bistrice do Mute in nato po Dravi v smeri proti Mariboru lahko v primeru katastrofe (porušitve jezu) poplavno ogrožena. Akumulacijsko jezero ima 16,2 mio. $\mathrm{m}^{3}$ ter bruto padec $735,50 \mathrm{~m}$.

\subsubsection{Meja $z$ Italijo}

\section{- Pravno - zgodovinski vidik}

Italija je imela v celotni zgodovini ozemeljske težnje po Sloveniji. Najbolj je prišlo to do izraza po I. svetovni vojni, ko si je uspela $\mathrm{z}$ raznimi pogodbami prisvojiti vso današnjo Primorsko, Trst, Reko, Zadar in del jadranskega otočja.

Po II. svetovni vojni, ko so partizanske enote NOV, kot sestavni del zavezniških sil osvobodile slovensko nacionalno ozemlje na zahodu (Italiji), so se začela mukotrpna mirovna pogajanja. Državna meja med Italijo in FLRJ (SFRJ) je bila določena $\mathrm{z}$ mirovno pogodbo, ki je del ozemlja razdelila na svobodno tržaško ozemlje (STO), ki je bilo razdeljeno v cono A in v cono B. Z londonskim memorandumom z dne 05.10.1954 je cona A pripadla Italiji in cona B takratni Jugoslaviji. Dokončno je bila meja med Italijo in Jugoslavijo pravno formalno določeno s podpisom pogodbe v Osimu 10.11.1975.

\section{- Odprta mejna vprašanja in možni učinki na varnost}

Italija je največja, najrazvitejša, najvplivnejša in najbogatejša, skratka politično in ekonomsko najpomembnejša soseda Slovenije, je članica Nata in ustanovna članica EU. Medsebojni odnosi so urejeni s priznanjem naše samostojnosti (priznanje 15. 01. 1992) in ureditvijo sukcesije (izmenjava not 31.07.1992), s katero so bili v nesporno veljavnost prevzeti vsi pomembni sporazumi, ki jih je z Italijo sklenila bivša SFRJ.

Ob bistveno spremenjenih geopolitičnih razmerah v Evropi in prevzemu oblasti v Italiji s strani skrajnih desničarjev (neofašistov) lahko meja med Italijo in Slovenijo postane sporna. V tem primeru bi lahko postale ozemeljske zahteve Italije do Slovenije bivša rapalska meja med Italijo in Jugoslavijo iz leta 1920, ali zahteva po »coni $\mathrm{B} \ll$ in zanikanje Londonskega memoranduma iz oktobra 1954.

Seveda je to bolj hipotetično vprašanje, ki ga moramo imeti vojaki vseeno upoštevati, saj kljub dobrim političnim, kulturnim in gospodarskim odnosom občasno prihaja do težav v odnosih, zlasti, če so na oblasti v Italiji »desničarske« stranke. Tako smo bili že v samostojni Sloveniji priča naslednjim potezam s strani Italije, ki niso v prid dobro sosedskim odnosom kot so:

1. Občasno ugovarjanje pravici Slovenije do nasledstva, ki sta ga obnovili obe državi 31.07.1992 (sukcesije nekdanje SFRJ);

2. Pritisk na spremembo Ustave (Oglej, Španski kompromis);

3. Pritisk Italije za vrnitev nepremičnin »razlaščencem« (ezulom);

4. Namestitev italijanske vojske na meji s Slovenijo (poleti 1993);

5. Serija pogojevanj okrog pogajanj Slovenije za pridruženo članstvo v EU; 
6. Uvedba komisarske uprave $\mathrm{v}$ Kmečki banki v Gorici;

7. Občasno poudarjanje domnevno težkega položaja italijanske manjšine v Sloveniji;

8. Zavlačevanje ureditve pravic slovenske manjšine v Italiji. Ustrezen zakon je v parlamentarni proceduri že več kot 20 let

9. Vsiljevanje tristranskega sporazumu o zaščiti italijanske manjšine $v$ Sloveniji in na Hrvaškem.

\subsubsection{Meja z Madžarsko}

\section{- Pravno zgodovinski vidik}

Prekmurje je imelo drugačen razvoj od ostalih slovenskih pokrajin, ker je spadalo pod ogrsko polovico habsburške monarhije.

Mirovna konferenca v Parizu je 26.5.1919 upoštevala predlog Jugoslavije, da dobi Prekmurje. Jugoslovanska vojska je intervenirala zoper revolucijo na Madžarskem in anektirala Prekmurje. Hkrati pa Mirovna konferenca ni dovolila, da bi jugoslovanska vojska zasedla Porabje. Državna meja med SFRJ in Madžarsko je nespremenjena od Trianonskega sporazuma, podpisanega 4. junija 1919. Kot taka je bila potrjena tudi z Mirovno pogodbo med Madžarsko in ostalimi državami, ki so sodelovale v drugi svetovni vojni. Mirovna pogodba je bila podpisana v Parizu 10. februarja 1947 (Murko, 1981:83).

Madžarska je tako kot Slovenija država v tranziciji, $s$ tem da je tudi ena izmed članic NATA. Značilnost slovensko-madžarskih odnosov je, vsaj po zatrjevanju politikov, da so odlični.

\section{- Odprta mejna vprašanja in možni učinki na varnost}

Tudi meje $\mathrm{z}$ Madžarsko so pravno formalno urejene s Trianonsko pogodbo. Kljub tej odličnostil ${ }^{11}$ pa se tudi na Madžarskem v skrajnih desničarskih krogih občasno pojavljajo zahteve po revidiranju slovensko-madžarske meje in odstop od Trianonske pogodbe, ki je bila podpisana 4.6.1919, Jugoslovanska vojska pa je zasedla Prekmurje avgusta 1919.

Seveda bi bile oz. so zahteve po meji na Muri samo teoretične oz. v bistveno spremenjenih geopolitičnih razmerah $v$ Evropi in prevzemu oblasti skrajnih desničarjev na Madžarskem ${ }^{12}$. V vojaškem smislu pa je obramba ozemlja na severovzhodu (meje) od vseh meja RS zaradi dobre prehodnosti najbolj problematična.

\subsubsection{Meja s Hrvaško}

\section{- Pravno zgodovinski vidik}

Meja Slovenije s Hrvaško ima tudi zgodovinsko tradicijo. Na večjem delu je bila to meja med avstrijskim in madžarskim delom Avstro-Ogrske monarhije, ki je bila sporazumno določena in $v$ naravi vidno označena. Po razpadu monarhije je bila $z$ nastankom Kraljevine SHS oziroma kraljevine Jugoslavije ta meja z manjšimi popravki prevzeta kot

11 Ob tem ne gre pozabiti "plakatne akcije«01.08.1999v Lendavi, ko so se ravno v času proslavljanja 80. letnice priključitve Prekmurja Sloveniji pojavile zahteve po spremembi meja oz. veliko Madžarskih apetitov ter protestov Madžarov leta 1990 ob 70 . Letnici podpisa Trianonske pogodbe (Ladislav Deak - Trianon - Illusions and reality).

12 Peter Klopčič v članku "Zunanja politika svobodne Slovenije«SSK 25.-28 junij 1991. je izrazito negativno ocenil Madžare kot (To so citati iz. omenjenega članka in jih je treba jemati zelo pogojno.):

- Madžari so od naših sosedov do Slovencev najbolj strupeno naperjeni;

- Madžari so v II. svetonni vojni dokazali, da so še vedno aziati:

- imajo probleme z vemi sosedi: Slovaki, Romuni. Ukrajinci, Srbi, Hrvati in Slovenci. 
meja med Dravsko in Savsko oziroma Hrvaško banovino. Ob začetku druge svetovne vojne ustanovljena Neodvisna država Hrvaška je takoj ob svojem nastanku začela urejati in $\mathrm{v}$ naravi označevati svoje meje. $\mathrm{S}$ takrat okupirano in med Italijo, Nemčijo in Madžarsko razdeljeno Slovenijo je bila skoraj v celoti prevzeta nekdanja banovinska meja, spremenjena le toliko, da so Mokrice prešle na hrvaško stran. Najmanj zgodovinske tradicije ima del meje, ki poteka po ozemlju, ki je do konca druge svetovne vojne pripadal Italiji. Na večjem delu gre pri tem za mejo, ki deli Istro na slovenski in hrvaški del, poteka pa od notranjskega Snežnika do Piranskega zaliva. Kot del meje med sosednjima republikama $v$ okviru takratne Jugoslavije je bila določena leta $1955^{13}$. Takrat določena meja je republiki Hrvaški dodelila del cone B Svobodnega tržaškega ozemlja, katerega južna meja je potekala po reki Mirni.

Državna meja na kopnem med Slovenijo in Hrvaško je določena, saj temelji na določilih »Temeljne ustavne listine«, ki pravi, da je: »meja Slovenijo in Hrvaško v okviru dosedanje Socialistične federativne republike Jugoslavije. Kljub temu je potrebno potek državne meje. ugotoviti na kopnem in jo določiti na morju. « Kljub temu je še vedno odprto vprašanje določitve pomorske meje med Slovenijo in Hrvaško. Zato je vlada RS na seji 29.04.1999 obravnavala to problematiko in $\mathrm{v}$ zvezi s tem sprejela sklep št. 003-01/98-3 (N) z dne 30.04.1999 po katerem je za posrednika o določitvi pomorske meje med Slovenijo in Hrvaško sprejela dr. Williama Perry-a (bivši obrambni minister ZDA).

\section{- Odprta mejna vprašanja in možni učinki na varnost}

Od $670 \mathrm{~km}$ meje, je po podatkih geodetov usklajeno $610 \mathrm{~km}$ meje, se pravi da je neusklajene okoli $60 \mathrm{~km}$ meje in 828 ha površin.

Po vodotokih (Bregana, Čabranka, Dragonja, Drava, Kamenica, Kolpa, Mura, Sava in Sotla) poteka $44 \%$ meje s Hrvaško. Sporna so zlasti premikanja strug Mure, Drave, Sotle in Dragonje. »Sporna« oziroma »neusklajena« območja so:

\section{Piranski zaliv}

To je prav gotovo najbolj trd oreh v pogajanjih o meji.

Piranski občini je celotni Piranski zaliv pripadal vse od 13. st. do 1. 1945. Ta pripadnost se je prekinila leta 1947 oziroma leta 1954 ko je takratna jugoslovanska oblast del Piranskega zaliva »dodelila« občini Buje in tako sta katastrski občini Savudrija in Kaštel pripadli Hrvaški. Kljub temu je Piranski zaliv ohranil status notranje morske vode (internal waters- inland sea) zato je slovenska policija izvajala nadzor celotnega zaliva.

Slovenija zastopa stališče, da je potrebno vse do sklenitve sporazuma o delimitaciji v Piranskem zalivu ohranjati stanje »status quo« kot ga je zaliv imel pred 25.06.1991. Tudi $v$ SFRJ je Slovenija imela in izvajala pravico do teritorialnega izhoda na odprto morje, ker meje med federalnimi enotami (republikami) na morju niso bile opredeljene.

Varnostnih, gospodarskih in tranzitnih interesov Slovenije ne more zagotavljati načelo neškodljivega prehoda, ker vključuje možnost enostranskega vsiljevanja ovir s strani

13 Viron, ki bi dokumentirali potek pogajanj, ki so privedla do končnih odločitev, ni mogoče dobiti. Po objavljenih časopisnih člankih naj bi delegaciji vsake strani vodila dr: Bakarić in Boris Kraigher: Slovenci naj bi se zavzemali za tak potek meje, po katerem bi bila Savudrija in s tem Piranski zaliv slovenska. V zameno so bili pripravljeni prepustiti Hrvaški nekaj ozemlja pri Bregani z. Mokricami. 
Hrvaške. Zato si Slovenija prizadeva za ozemeljsko morje (territorial sea) in s tem do direktnega dostopa na odprto morje. Hrvaška seveda vztraja na načelu sredinske črte, po določilih mednarodnega prava, ki si ga razlaga po svoje in ne upošteva argumentov Slovenije. Ne glede na to, kako bo rešen, gre v luči evropskih oziroma svetovnih razmer za sorazmerno majhen problem, saj gre za razliko $200 \mathrm{~m}$, tako da ves sporni teritorij zavzame 113 ha, ali $0,01 \%$ hrvaške in $0,45 \%$ slovenske obale.

\section{Istra - Dragonja}

Po II. Svetovni vojni je reka Dragonja veljala za etnično mejo med Slovenijo in Hrvaško. Slovenija zagovarja da so naselja Škodelin, Mlini, Bužini in Škrile slovenska in tudi prebivalci se imajo za Slovence ${ }^{14}$.

3. Snežnik - Babno polje (Tomšičeva parcela)

Gre za neskladja med sosednima katastrskima upravama.

4. Bela Krajina: Brezovica - Radovica, Bušinja vas, Dolenji Suhor, Bojanja vas

Tu je najbolj nenavaden potek meje. Nenaravno se zajeda enkrat v slovensko, pa v hrvaško ozemlje. V Radovico se po cesti lahko pripeljete samo preko ozemlja RH.

\section{Trdinov vrh / Gorjanci}

Po katastrskih podatkih obeh držav naj bi bil vojaški objekt na Hrvaški strani.

\section{Sotla}

Problem je v regulaciji struge in enostranskih izmer s strani $\mathrm{RH}$.

\section{Rogatec}

Problem je nastal zaradi regulacije Sotle in gradnje železniške proge Rogatec - Zabok

\section{Ormož}

Problem je nastal zaradi regulacij mejnih potokov.

\section{Ljutomer / Gibina - Razkrižje}

Problem je $\mathrm{v}$ neusklajenosti med obema katastrskima upravama in premik meje s strani Hrvaške mimo predpisov.

\section{Mura / Dolinsko}

Problem je nastal, ker je Hrvaška v času 1956 - 1960 enostransko izvajala nove meritve Medimurja,

Seveda so $\mathrm{v}$ medsebojnih odnosih med $\mathrm{R}$ Slovenijo in $\mathrm{R}$ Hrvaško odprta tudi druga vprašanja, kot so gospodarska (JE Krško, Ljubljanska banka v Zagrebu in počitniški domovi, ki pa se intenzivno rešujejo)

V primeru zaostritve odnosov bi se pojavila dodatna vprašanja, ki so povezana z določitvijo meje in ureditvijo medsebojnih vprašanj kot:

- komunalno vprašanje: deponije odpadkov in onesnaževanje okolice (Ribnica)

- rižanski in istrski vodovod: Gradole ter črpališči Bužin in Gabrijeli

- letališče Sečovlje: vzlet letal v zračni prostor Hrvaške

- problematika telekomunikacij: Osilnica

- pokopavanje umrlih: Petrina - Podplana

- oskrba z električno energijo iz Hrvaške: v delu občine Črnomelj

- rezervat pitne vode na Gorjancih

in drugi infrastrukturni in komunalni problemi, ki bi lahko $\mathrm{v}$ primeru zaostrovanja odnosov vplivali na varnost $\mathrm{RS}$.

I4 Zadnji primer občinskega svetnika Jožka Jorasa in problem prevoza omare na naslov Sečovlje I. 
Da so nekateri »eksperti« zelo nacionalistično usmerjeni, dokazuje tudi hrvaški publicist Peter Vučić, ki v svojih prispevkih (Politička sudbina Hrvatske - Mladost, Zagreb 1995) postavlja nekatere zelo $»$ problematične teze $\ll 15$.

\section{SKLEP}

Za teritorialno oblikovanje Republike Slovenije v 20. stoletju lahko ponazorimo z izrekom »BOJI ZA MEJE SLOVENIJE«.

Do leta 1914 v sestavu Avstro-Ogrske monarhije, po prvi svetovni vojni boleča izguba ozemelj na severu in zahodu ter prvi boji za meje Slovenije.

Po II. svetovni vojni, pridobitev ozemelj na zahodu (Primorska) in drugi boji za Slovenijo, ter tretji boji za meje Slovenije v obdobju osamosvajanja 1990/1991 ter končno uresničen stoletni sen Slovencev o zedinjeni Sloveniji.

Od $75.000 \mathrm{~km}^{2}$ ozemlja, ki so ga poseljevali Slovenci v obdobju po 18. stoletju ima samostojna Slovenija $20.256 \mathrm{~km}^{2}$. Slovenija ima izjemno pomemben geostrateški položaj na stičišču nekaterih večjih naravnih geografskih enot Evrope (alpska, mediteranska, dinarsko kraška in subpanonska oz. panonska). Je umeščena v prehodno območje med Jugozahodno, Vzhodno, Srednjo in Zahodno Evropo ter na stičišču velikih etničnih skupin Evrope (slovanske, romanske, germanske in ugrofinske). Ima urejene meje s sosedami, razen delno s Hrvaško. Meje in geografski prostor RS ima izrazito trikotno obliko in je zaradi tega varnostnega in obrambnega vidika problematična.

Je v geopolitčno stabilnem okolju, ki ji omogoča demokratičen razvoj in življenje v miru. Ob bistveno poslabšanih geopolitičnih razmerah v Evropi in prihodov skrajnežev na oblast v sosednjih državah, lahko meje in »sporna obmejna območja ter njihove ozemeljske težnje ponovno postanejo predmet sporov. Vendar je to majhna verjetnost, ki pa jo moramo imeti kot vojaki vedno pred očmi.

\section{LITERATURA IN VIRI}

- Bratun, Z.,1998 a: Geografski dejavniki državnovarnostnega sistema Republike Slovenije. Doktorska disertacija, Filozofska fakulteta, Oddelek za geografijo, Ljubljana.

- Bratun, Z.,1998 b: Geografska dimenzija nacionalne varnosti in medetničnih konfliktov v Republiki Sloveniji in Demografska dimenzija nacionalne varnosti in medetničnih konfliktov $v$ Republiki Sloveniji, v: Mitar M. (ur) Nacionalna varnost in medetnični konflikti, Zbornik, Visoka policijska in varnostna šola, Ljubljana.

- Bratun, Z.,1999: Uresničevanje geopolitične doktrine Republike Hrvaške po Petru Vučicu; Tipkopis, Ljubljana.

15 Hrvaška naj bi segala od Soče do Drine,

- Hrvaška je izgubila »Karantanijo« - zdi se za vedno

- Slovence poimenuje kot »Planinske Hrvate«.

Ko analizira geopolitični položaj, sta zanimivi dve tezi:

1. Slovenija je izolirala Hrvaško od Avstrije in naprej proti severu (Nemčijo) kot negativen predznak in

2. Slovenija je tamponsko območje v razmerju do Italije - kot pozitiven predznak.

Po njegovem ima Hrvaška urejene meje samo z Madžarsko, z ostalimi sosednjïni državami pa so neurejene, torej SPORNE, ki pa so najpogostejši vzrok in povod vojnam. Torej je pred Hrvaško nemirno obdobje, obdobje vojn za katere se mora pripraviti.

To je samo del povzetkov iz gradiva »Uresničevanje geopolitične doktrine RH po Petru Vućiću«, ki mi ga je prijazno odstopil dr: Bratun. Tudi v prihodnje bo potrebno skrbno spremljati podobne »eksperte kot so P. Vućić na Hruaškem. 
- Deak, L., 1995: Trianon - Illusions and reality, Bratislava.

- Gams, I., 1996: Geografske značilnosti Slovenije, Mladinska knjiga, Ljubljana

- Grafenauer, B., 1994:Oblikovanje severne slovenske narodnostne meje, Zbirka zgodovinskega časopisa, Ljubljana.

- Grabnar, M., 1991: Zapiski, Osebni dnevnik, Novo mesto.

- Klemenčič, V., 1992a: Državna meja na območju Slovenije in mejna območja kot nov geografski fenomen, v Nendl D. (ur) Slovenski svetovni kongres, Ljubljana 25. - 28. junij 1991,Tretja Slovenska univerza, Seminar za študije geopolitičnega položaja Slovenije. Ministrstvo za znanost in tehnologijo, Ljubljana, str. 81-106.

- Klemenčič, V., 1992a: Geopolitični položaj Slovenije in njena odprtost v Evropo, Geografija v šoli, 6. Ilešičevi dnevi, 21. - 22.2.1992, Ljubljana.

- Klemenčič, V., 1994: Prostorsko strukturne spremembe Slovenije kot nove države, v Znanstvena revija; Družboslovje in filozofija št. 6; Pedagoška fakulteta, Maribor.

- Klopčič, P.,1992: Zunanja politika svobodne Slovenije, v: Nendl D. (ur) Slovenski svetovni kongres, Ljubljana 25. - 28. junij 1991, Tretja Slovenska univerza, Seminar za študije geopolitičnega položaja Slovenije. Ministrstvo za znanost in tehnologijo, Ljubljana,

- Kranjc, M., 1998 Balkanski vojaški poligon, v: Revija Borec, Ljubljana.

- Ministrstvo za zunanje zadeve, 1997: Pariška mirovna pogodba, Integralno prevodno besedilo, Ljubljana.

- Mlakar, G., 1996: Meje, posestne in državne, EPSI, d.o.o., Nazarje.

- Nendl, D., 1992: Pred svetovnim slovenskim kongresom - Ne razprodajajmo slovenske zemlje v: Nendl D. (ur) Slovenski svetovni kongres, Ljubljana 25. - 28. junij 1991,Tretja Slovenska univerza, Seminar za študije geopolitičnega položaja Slovenije. Ministrstvo za znanost in tehnologijo, Ljubljana.

- Osimski sporazumi, 1997: Osimski sporazumi, Založba Lipa, Koper .

- RŠTO, 1991: Načrt »KAMEN«, št. SZ 804-03/112 z dne 19. 04. 1991, Ljubljana

- Sabadin, D., 1995: Problemi in dileme pri določanju slovensko-hrvaške državne meje Diplomsko delo, Fakulteta za družbene vede,Univerza v Ljubljani, Ljubljana.

- Sedar, D., 1998: Plebiscit na Koroškem 10. oktobra 1920, Diplomsko delo, Fakulteta za družbene vede, Univerza v Ljubljani, Ljubljana.

- Stourzh, G., 1975: Avstrijska državna pogodba (Kleine Geschichte des Osterreichischen Staatsvertrages, Mit. Dokumententeil Styria.

- Uprava RS za zaščito in reševanje, 1998: Ocena ogroženosti ljudi in materialnih dobrin ob porušitvi pregrade za He »Golica« v: Elaborat za izvajanje vaje »Golica-Koralpe-98«-Uprava RS za zaščito in reševanje, Ljubljana.

- Vlada Republike Slovenije, 1991: Pravilnik o izvajanju Zakona o nadzoru državne meje in Zakon o nadzoru državne meje, Uradni list Republike Slovenije številka 19/91, Ljubljana.

- Zvezna Skupščina SFRJ, 1966: Uredba o ratifikaciji ugovorov, Uradni list SFRJ, številka 11/66, Beograd.

- Zbornik, 1998: Vprašanja oblikovanja slovenskega etničnega in državnega prostora s pomembnim poudarkom na slovensko hrvaški meji v Istri, Zbornik referatov okrogle mize - Portorož $21 / 2.1998$.

\section{SUMMARY:}

The area, whose population are Slovenians was reduced through centuries from 75.000 $\mathrm{km}^{2}$ in the 18 th century to $20.256 \mathrm{~km}^{2}$, and that is also the today's measurement of independent Slovenia, and the part of territory in Italy, Austria and Hungary, which is also poulated by Slovenians.

The geopolitical meaning of this area was, is and will forever be extremely important. 
Slovenia has legally regulated borders with all the neighbours, with the exception of the Croatian border, which still has to be defined. During the independence period Slovenia has shown great attention towards the borders. Slovenia also made and carried out very important plans from military point of view how to secure the borders.

If we look through the eyes of history, the changed geopolitical circumstances, borders and the »controversary « frontier"areas could become a part of conflicts and could become tense in this part of Europe.

With the democratical development, economical prosperity in the future and with an active effort of Slovenia to become a member of UE and NATO, Slovenia will have on a long term, stabile geopolitical position.

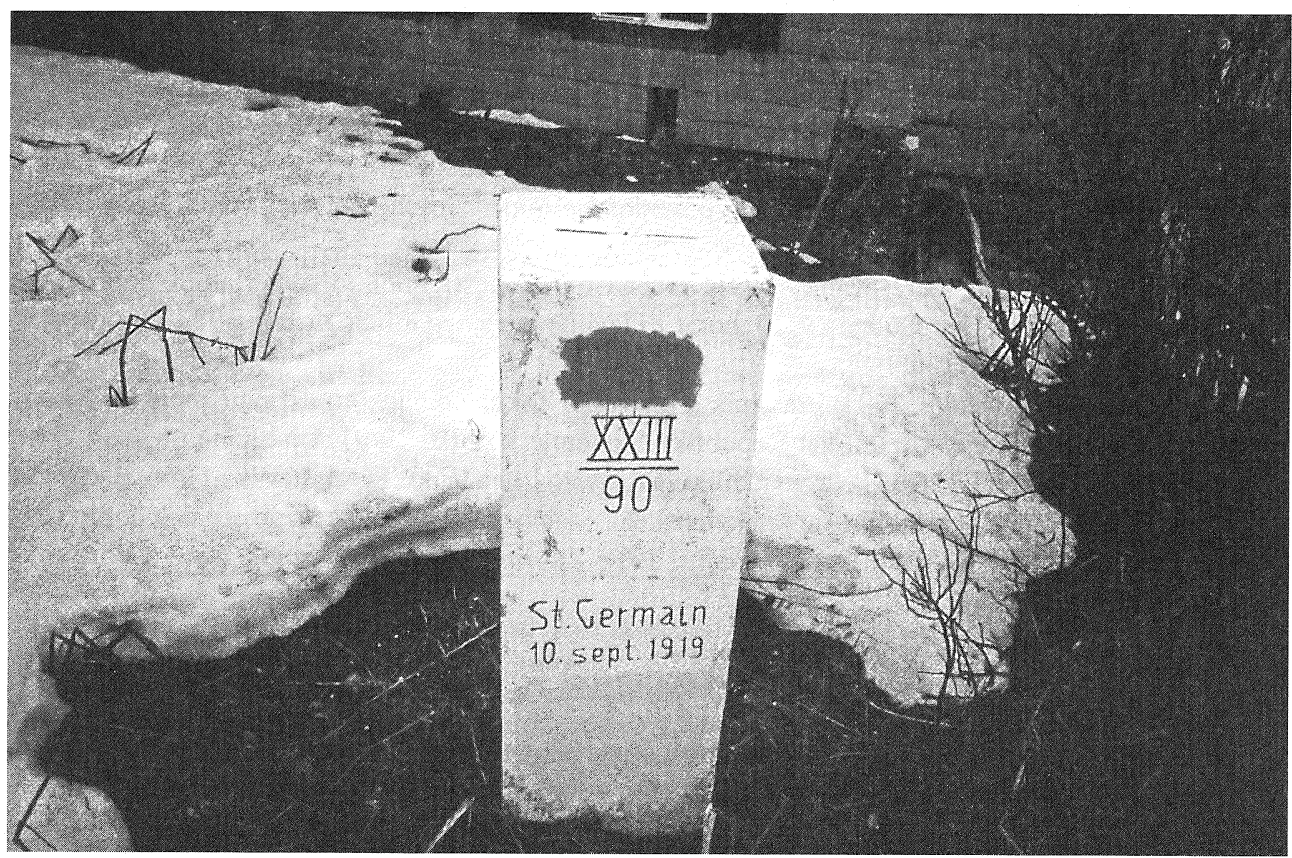

Slika 1: Mejni kamen št. XXII/90, Slovensko-avstrijska meja.

Foto: Zvonimir Bratun, marec 1994 